Turkish Economic Liberalization and European Integration

Author(s): Meltem Müftüler

Source: Middle Eastern Studies, Vol. 31, No. 1 (Jan., 1995), pp. 85-98

Published by: Taylor \& Francis, Ltd.

Stable URL: https://www.jstor.org/stable/4283700

Accessed: 31-01-2019 17:25 UTC

JSTOR is a not-for-profit service that helps scholars, researchers, and students discover, use, and build upon a wide range of content in a trusted digital archive. We use information technology and tools to increase productivity and facilitate new forms of scholarship. For more information about JSTOR, please contact support@jstor.org.

Your use of the JSTOR archive indicates your acceptance of the Terms \& Conditions of Use, available at https://about.jstor.org/terms

Taylor \& Francis, Ltd. is collaborating with JSTOR to digitize, preserve and extend access to Middle Eastern Studies 


\title{
Turkish Economic Liberalization and European Integration
}

\author{
MELTEM MÜFTÜLER
}

In many ways, the political and economic history of modern Turkey has been an attempt to catch up with, or adapt to, the developments in the rest of Europe. These attempts have gained an especial momentum since 1980. Substantial changes have taken place in the Turkish economy since 1980 with respect to the basic economic principles of the European Community. ${ }^{1}$ This article will address the extent to which economic reforms undertaken in the 1980s were shaped by the Turkish policy-makers' concerns on the ramifications of the ongoing European integration on the Turkish economy and the Turkish desire to be 'a part of the team' rather than a spectator. In this view, Turgut Özal, the Prime Minister of Turkey between 1983 and 1989, and the President from 1989 to his death in April 1993, summarized succinctly the motives behind the economic reforms of the 1980s: "the aim of the economic liberalization programme and our reforms was to facilitate our integration into the European Community as a full member'.2

Modern Turkey has made a strong commitment to the Western order as a staunch European ally. Turkish political elite of differing persuasions is unanimous on Turkey's future as a European nation, and since the European Union is the future of Europe, Turkey's future is with the EU. The choice made by Turkey to link her future with that of Europe is not a recent one, nor was in 1963 when the association agreement was signed with the Europe of the Six. It can be traced back to the 1920s. ${ }^{3}$ The 1963 EC-Turkish Association Agreement (The Ankara Treaty) has initiated the process of more closely incorporating the Turkish economy into the EC with an eye towards an eventual full Turkish membership in accordance with Article 28 of the Treaty. In 1970 the Association Agreement was modified by the Additional Protocol with the ultimate aim of attaining a customs union between the EC and Turkey by 1996. On 14 April 1987 the Turkish government applied for full membership of the EC, yet the road to full accession was to be long and winding. ${ }^{4}$ On 17 October 1991 Turkey signed an agreement with European Free Trade Association (EFTA) countries with the aim of incorporating Turkey into the European Economic Area and opening it to a market of both EU and EFTA countries. The latest development in EU-Turkish relations is the customs 
union to be realized at the end of 1995 . The significance of the customs union is that if it is realized, then Turkey will be the first country that has achieved customs union with the EU without being a member first.

The EC as a major trade bloc and an emerging sovereign unit on the international scene is a political economic reality to be reckoned with. Access to the EC market has been an imperative to economic growth for many developing countries lying on the fringes. For Turkey, exclusion from the European trading bloc which is moving towards single market within the framework of the 1992 programme would mean economic and political isolation when already, many more have entered into special agreements so as to mitigate undesired economic effects, such as trade diversion. ${ }^{5}$

The Turkish government is all too aware of this danger. One of the former directors of the State Planning Institute's European Community Department, has explained the impact of the EC on Turkey:

In order to overcome the economic obstacles that lay on the way of economic integration between Turkey and the Community, the government has sought to create a new economic order since 1980 through structural changes, new infrastructure, economic liberalization and trade reforms. These reforms have been motivated by the Turkish anxiety of being left out of the new European order that is in the making since the adoption of the internal market programme. $^{6}$

Thus, the economic reforms in Turkey during the 1980s can be seen as an attempt to adapt to the newly emerging system in Europe. This, however, is not a denial of other exigencies impinging upon Turkish policy-making. Multilateral institutions such as International Monetary Fund (IMF), World Bank and the Organization for Economic Cooperation and Development (OECD) have all been influential in drawing up the economic strategies to deal with the Turkish 'mini' debt crisis in 1977 and subsequent economic liberalization attempts. These, however, have been complementary to the ultimate aim of Turkish economic restructuring in order to have compatibility with the standards of the EC.

During the 1980s the EC underwent an enlargening and a deepening process which altered the external economic environment for Turkey. The enlargement aimed at incorporating Spain, Portugal and Greece as new members of the EC and the deepening process was a move towards the realization of the internal market programme by the end of 1992 .

The first component of the changes in the EC indirectly influencing Turkey is the process of European integration which gained momentum 
with the adoption of the White Paper by the Commission on 14 June 1985. The White Paper is a set of proposals presented by Lord Cockfield to the Commission in order to eliminate physical, financial and technical barriers to trade among the EC member states. ${ }^{7}$ The ultimate aim is to create an area without any frontiers by 31 December 1992. To enact the White Paper proposals, the European Parliament ratified the Single European Act (SEA) in 1987. The White Paper and SEA as the instruments of European integration have contributed to the emergence of 'fortress Europe' which culminated in the historic Maastricht Treaty in December 1991 for a united EC.

The second component of the changes within the EC affecting Turkey is the European financial integration through the European Monetary Union which started with a plan introduced in April $1989 .{ }^{8}$ In order to be a single market, Europe also has to have a single currency. ${ }^{9} \mathrm{~A}$ free and integrated European financial area is the essential precondition for the realization of the Single Market in goods and services,,$^{10}$ so a major element of European integration is the establishment of EMU and the European Central Bank.

The third component of the changes in the EC relevant to the purposes of this study is the Mediterranean enlargement of the Community that incorporated Greece (1981), Spain and Portugal (1986) as full members.

These developments have greatly altered the face of Europe by establishing an internal market among the twelve members of the EC through a customs union. The creation of a customs union will affect trade in a number of ways. As barriers are lifted, trade between the members of the union will grow; this is the trade creation effect. However, the union will also lead to a decrease in trade between the members of the union and non-members; this is the trade diversion effect.

The creation of an internal European market means that the elimination of all non-tariff barriers among its members will displace the exports originating from third parties; Turkey, as a country whose exports are oriented to the EC, will be severely affected by this process (see Tables 2 and 3). Thus, the European integration to be realized through such measures as the White Paper, SEA and the Maastricht Treaty, poses a threat on countries like Turkey located on the fringes of the EC, since it is possible for an enlarged market to exhibit a strong centripetal tendency, causing the non-members to suffer an absolute decline.

As for the second enlargement, the negative effect of the Spanish, Greek and Portuguese accession to the EC on the exports of non-partner countries - especially Turkey - is significant (see Table 4). ${ }^{11}$ For the nonmember Mediterranean countries, the enlargement means a loss of markets because: (i) the rest of the EC now has free access to new 
members' markets; (ii) they now face CET in the new members' markets; (iii) their exports to the EC are displaced by those of the new members; and (iv) it increases competition for new members in their domestic markets now that they have to accept existing preferential trade agreements. ${ }^{12}$ As a result of these losses, non-member Mediterranean countries, such as Turkey, are left with the hard task of adapting to the changing conditions. They have to penetrate inside via either full entry or make more trade concessions. Either way, the country in question has to go through some major changes in order to prepare and adapt itself to the altered external environment. Whether these neighbours of the EC are seeking new forms of relations with the EC or full membership of the EC, the evidence points in one direction. In late 1980s and early 1990s, the EC has become a magnet for its fellow Europeans. ${ }^{13}$

TABLE 1

TURKISH EXTERNAL TRADE WITH THE EC ${ }^{35}$

(accounts in million \$)

\begin{tabular}{crc} 
Year & Imports & Exports \\
\hline 1963 & 196.1 & 139.9 \\
1964 & 154.5 & 137.7 \\
1965 & 163.2 & 156.9 \\
1966 & 236.5 & 171.4 \\
1967 & 231.9 & 176.7 \\
1968 & 281.9 & 164.1 \\
1969 & 284.5 & 215.9 \\
1970 & 325.2 & 239.1 \\
1971 & 367.8 & 325 \\
1972 & 467.5 & 422.6 \\
1973 & 1,102 & 612 \\
1974 & 1,662 & 717 \\
1975 & 2,338 & 615 \\
1976 & 2,342 & 959 \\
1977 & 2,470 & 868 \\
1978 & 1,873 & 1,090 \\
1979 & 1,828 & 1,098 \\
1980 & 2,203 & 1,242 \\
1981 & 2,519 & 1,503 \\
1982 & 2,466 & 1,755 \\
1983 & 2,596 & 2,066 \\
1984 & 2,974 & 2,781 \\
1985 & 3,547 & 3,204 \\
1986 & 4,565 & 3,263 \\
1987 & 5,668 & 4,868 \\
1988 & 5,894 & 5,098 \\
1989 & 6,055 & 5,408 \\
1990 & 9,328 & 6,906 \\
1991 & 9,221 & 7,042 \\
1992 & 10,063 & 7,460 \\
1993 & 12,301 & 7,242 \\
\hline
\end{tabular}


TABLE 2

TURKISH IMPORTS ${ }^{36}$

\begin{tabular}{cccc} 
Year & Imports $(\$)$ & Imports from EC & $\%$ EC \\
\hline 1979 & 4,946 & 1,708 & 34.5 \\
1980 & 7,815 & 2,268 & 29.2 \\
1981 & 8,864 & 2,519 & 28.4 \\
1982 & 8,794 & 2,466 & 28.4 \\
1983 & 9,179 & 2,596 & 28.3 \\
1984 & 10,663 & 2,974 & 27.8 \\
1985 & 11,275 & 3,547 & 31.5 \\
1986 & 11,020 & 4,565 & 41.4 \\
1987 & 14,093 & $5,667.8$ & 40.0 \\
1988 & 14,267 & $5,894.2$ & 41.1 \\
1989 & 15,686 & $6,054.8$ & 38.4 \\
1990 & 22,302 & 9,328 & 41.8 \\
1991 & 21,047 & 9,221 & 43.8 \\
1992 & 22,872 & 10,063 & 44.0 \\
1993 & 29,429 & 12,301 & 41.8
\end{tabular}

TABLE 3

TURKISH EXPORT PERFORMANCE ${ }^{37}$

\begin{tabular}{llll} 
Year & $\begin{array}{l}\text { Exports } \\
\text { (merchandise) }\end{array}$ & $\begin{array}{l}\text { Exports to EC } \\
\text { (million \$) }\end{array}$ & $\begin{array}{l}\text { Exports to EC } \\
\text { as \% }\end{array}$ \\
\hline 1979 & 2,261 & 1,132 & 50.0 \\
1980 & 2,910 & 1,300 & 44.7 \\
1981 & 4,703 & 1,564 & 33.3 \\
1982 & 5,890 & 1,802 & 31.4 \\
1983 & 5,905 & 2,066 & 36.1 \\
1984 & 7,389 & 2,781 & 39.0 \\
1985 & 8,255 & 3,204 & 40.3 \\
1986 & 7,583 & 3,263 & 43.8 \\
1987 & 10,190 & 4,868 & 47.7 \\
1988 & 11,662 & 5,098 & 43.7 \\
1989 & 11,627 & 5,408 & 46.5 \\
1990 & 12,959 & 6,906 & 53.2 \\
1991 & 13,594 & 7,042 & 51.8 \\
1992 & 14,715 & 7,460 & 50.7 \\
1993 & 15,344 & 7,242 & 47.2 \\
\hline
\end{tabular}

TABLE 4

SIMILARITY INDEX OF EEC PRIMARY PRODUCT IMPORTS FROM THE THREE AND FROM THE MEDITERRANEAN COUNTRIES ${ }^{38}$

\begin{tabular}{llcll} 
& Greece & Portugal & Spain & Three \\
\hline Morocco & 43.9 & 22.5 & 55.7 & 55.4 \\
Turkey & 64.8 & 13.7 & 47.1 & 52.8 \\
Israel & 43.8 & 8.0 & 51.6 & 45.6 \\
Tunisia & 30.6 & 16.8 & 36.9 & 37.7 \\
Cyprus & 43.1 & 10.7 & 63.2 & 57.1 \\
Malta & 29.0 & 2.9 & 29.1 & 25.8 \\
\hline
\end{tabular}


TABLE 5

EFFECTIVE TARIFF RATES ON IMPORTED GOODS ${ }^{39}$

\begin{tabular}{llll} 
Year & Overall & Petroleum & Other \\
\hline 1979 & .43 & .16 & .56 \\
1980 & .12 & .04 & .20 \\
1981 & .11 & .03 & .13 \\
1982 & .10 & .02 & .16 \\
1983 & .12 & .02 & .19 \\
1984 & .10 & .01 & .14 \\
1985 & .09 & .01 & .12 \\
\hline
\end{tabular}

TABLE 6

REAL EXCHANGE RATES 1979-91 ANNUAL AVERAGES ${ }^{40}$

\begin{tabular}{ccc} 
Year & $\begin{array}{l}\text { Annual Ave. } \\
\text { Rate RER }\end{array}$ & $\begin{array}{c}\text { Nominal Exc. } \\
\text { Rate (TL/\$) }\end{array}$ \\
\hline 1979 & 156.9 & 31.1 \\
1980 & 109.1 & 76.0 \\
1981 & 104.3 & 111.2 \\
1982 & 107.8 & 162.6 \\
1983 & 103.0 & 225.5 \\
1984 & 96.7 & 366.7 \\
1985 & 97.3 & 522.0 \\
1986 & 87.2 & 674.5 \\
1987 & 82.1 & 857.2 \\
1988 & 104.2 & $1,422.4$ \\
1989 & 108.3 & $2,121.7$ \\
1990 & 114.6 & $2,608.6$ \\
1991 & 111.9 & $4,169.9$ \\
\hline
\end{tabular}

The enlargement of the EC is in a direct sense concerned with real trade and investment flows and the EC cum 1992 shock poses macroeconomic challenges for non-member states in the EC's orbit. As for the financial integration of the EC, when the 1992 legislation on financial markets removes all formal restrictions on capital movements, it will not be possible for a country which pegs its exchange rate to the EMU grid to pursue an independent monetary policy. Even a country which is outside the EMS but targets its exchange rate on the European Monetary System (EMS), say by stabilization of the real exchange rate with the EMS, will forfeit an independent monetary policy. This seems to be a striking example of convergence, in this case of macroeconomic policies. ${ }^{14}$ The objective of monetary integration within the EMU provides a challenging economic motive for Turkey, because it requires the solution of structural problems, the convertibility of the Turkish lira, the reduction of the 
inflation rate to the average inflation rate of the $\mathrm{EC}$, and the adjustment of macroeconomic policies. ${ }^{15}$

To sum up, the developments within the internal structure of the EC during the 1980s necessitate certain changes in the Turkish economy. In addition, Turkey aims at full membership of the EC, as its 1987 application has demonstrated, and also is looking towards a customs union scheduled for 1996. These, in turn, require substantive restructuring and liberalization of the Turkish economy.

The Turkish economy, from the creation of the new republic in 1923 to 1980 , was characterized by central planning and inward-looking policies. At the end of the 1970s, the economy was burdened with high rates of inflation, large budget deficits and an international debt. A reform programme deemed necessary.

On 24 January 1980 the Turkish government announced a major stabilization and liberalization programme with which Turkey for the first time embarked on a set of policies aimed at the permanent transformation of the economy and the nature of government-economic relations. ${ }^{16}$ The short-term goal of the programme was to stabilize inflation and cope with the balance of payments problem, the long-term goal was to liberalize and restructure the Turkish economy so as to enable a convergence with the EC standards. The liberalization programme heralded the end of fifty years of protectionism and marked the beginning of a period of farreaching structural changes leading to a market economy. ${ }^{17}$

The outward- and market-oriented transformation ${ }^{18}$ Turkey underwent rested on policies to restrain the growth of domestic demand and on structural reforms to augment supply through an improved allocation of resources. To do so, economic policies that reduce or eliminate restrictions on foreign trade and/or capital transactions, as well as price controls, government subsidies and state investments were adopted. ${ }^{19}$

Burdened by staggering inflation and an increasingly worsening balance of payments, the government introduced this orthodox stabilizationwith-liberalization programme under the auspices of the International Monetary Fund. The objectives were: (i) coping with immediate pressures on the balance of payments; (ii) eliminating disequilibria in major markets; (iii) breaking the inflationary spiral, reducing inflation and eventually attaining price stability; (iv) privatizing state enterprises; and (v) liberalizing foreign trade and payments as a part of the efforts to shift to a sustainable balance of payments position..$^{20}$

During the 1980 s, there was an interest in the international community towards the Turkish adjustment programme which provided the much 
needed continuous support from the multilateral organizations such as the EC, IMF and OECD. The IMF supported the programme by a standby agreement and the World Bank gave structural adjustment loans which in turn helped rescheduling the commercial debt. The role of the EC was different from the IMF and the World Bank in the sense that the EC did not provide a direct stimulus to the adoption of this liberalization programme, but these reforms enabled Turkish governments to pursue their desire to be accepted as the 13th member of the EC and to prepare for the customs union. 'If Turkey is to flourish in the European Community, its private sector must be ready and able to compete. Just how ready and how strong is it? The answer in 1980 would have been easy: hardly at all. Few in industry were looking for full membership. ${ }^{, 21}$ Thus, it was hoped that the reform programme would help overcome the structural disparities between the European and Turkish economy. ${ }^{22}$ One can evaluate the EC's impact on Turkish economic policies in Turkey's adoption of value added tax (VAT) prior to the majority of the EC countries. According to Özal, this was a measure taken in reference to EC, since the Turkish VAT legislation was prepared with respect to the laws and practice of the $\mathrm{EC}^{23}$ even though Turkey was not a full member.

To prepare for full membership of the EC, major changes have been adopted in the field of foreign trade. The role of the state in the economy has been re-evaluated in accordance to the Rome Treaty, and a number of measures have been taken to reform the State Economic Enterprises. Also, in the financial and banking sectors, which are the sectors that affect the Turkish and EC relations the most, certain readjustments have been made. ${ }^{24}$

Prior to 1980 , the tariffs were very high and there were strict quantitative restrictions on imports. If the authorities decided that the domestic production of a specific good was adequate, it meant that the good could not be imported legally. The 1980 decisions made a major break with those policies by dismantling trade restrictions. The measures on the import front were sharp reductions in stamp duty ${ }^{25}$ guaranteed deposits on imports, a simplification of import procedures, and a programme to abolish the list of goods subject to global quotas which represented 12 per cent of total imports in 1980 .

Some of these tariff reductions on imports were actually a part of the Additional Protocol reductions that Turkey had agreed upon in 1970, but because of the import substitution policies of the 1970s, they were not adopted, which gave the EC the excuse not to fulfil its own obligations. However, largely owing to its liberalization programme, Turkey in 1988 was able to make a 10 per cent reduction in 12 - and 22 -year lists of the 
Additional Protocol with the EC as stipulated by the agreement towards the customs union, and on 1 January 1989 Turkey was able to make a 20 per cent reduction as an attempt to adjust to the Community's Common Customs Tariff. In 1994, 60 per cent of the tariff reductions on the 12-year list and 50 per cent of the 22-year list have been enacted by the Turkish government. Thus, the import liberalization strategies adopted by the Turkish government sought to open up the Turkish economy to the European forces, and to prepare the Turkish economy for full integration into the Community as an official member ${ }^{26}$ because 80 per cent of all the liberalization measures applied to imports from the EC.

The stabilization and liberalization programme greatly increased the incentives to export and aimed at tackling a twofold problem inherited from the 1970s: soaring inflation and a balance of payments crisis. The assumption was that export promotion would lead to an improvement in the balance of payments; that, in turn, would favourably affect the import of capital goods, raw materials and other inputs; expanding the supply capacity of the economy. The period of export growth, beginning in 1980 , coincided with substantial real depreciation and expanded export subsidies, implying a clear statistical correlation between improved incentives for exporters and export growth. ${ }^{27}$ Another motive for export promotion was to bring a boost to the Turkish industry and strengthen the Turkish industries so as to prepare for full membership in the EC and for EC 1992.

However, the export promoting measures were not viewed so favourably by the Community. On 17 March 1989, the European Parliament passed a resolution accusing Turkey of unfair competition because of its export promotion incentives and threatened Turkey by not fulfilling its own obligations for the customs union to be realized in 1996. A few months later Turkey eliminated export subsidies and tax rebates on exports as a response to the EC's unfair competition claims. In 1989 all monetary incentives to exports had been lifted; however, the government adopted new measures to encourage exports, such as performance and pre-shipment credits, fund refunds, corporate income tax exclusion, and premium payments from Support and price Stability Funds which were very similar to the export incentives the Community members used for their own exporters.

Until 1980 Turkey operated a rigid system of exchange control originally established to protect the value of its currency. The 1980 programme immediately devalued Turkey's exchange rate by 48.6 per cent, after which the Turkish lira was constantly devalued. The assumption was that rolling back the real consequences of an undervalued exchange rate by creating extra inflation is less costly than repairing the consequences of an overvalued exchange rate by contractionary policies. Turkey became 
dependent on exchange rate movements as the major external policy instrument so that quantitative restrictions were dismantled and tariff and export incentives were reduced. ${ }^{28}$ In May 1981 the policy-makers institutionalized the policy of broad maintenance of an unchanged real effective exchange rate through daily changes in the nominal rate (Table 6). The government's substantial devaluation of the Turkish lira led to the depreciation of the exchange rate more or less continuously against convertible currencies in order to offset relative price developments and to ensure the competitiveness of the Turkish lira; and a major step was taken in the direction of making the Turkish lira a fully convertible currency.

The financial integration of the EC forces the members as well as the non-member countries with close ties with the EC to adapt monetary measures to cope with this financial change. Therefore, it would not be far-fetched to claim that one of the underlying reasons for the Turkish exchange rate reforms was to adapt and prepare the Turkish lira for the newly emerging EMS. Since the lira was almost always overvalued and was not a hard currency, steps were taken to remedy these problems and to facilitate the Turkish currency's adjustment to the EMS. Thus, the Turkish lira was being prepared for integration into the EMS as it progressed towards full convertibility by finding its real value instead of its overvalued self of the 1970s, with 'the aim as to have an increasing degree of convertibility of the Turkish lira for an ever increasing degree of monetary integration with the EC'. ${ }^{29}$

The 1980 programme was accompanied by financial liberalization. Until 1980 institutional interest rates, fixed by administrative decisions, were not used as an instrument of macroeconomic policy, but in July 1980 interest rates were freed and rationalized based on the assumption that higher interest rates would stimulate savings, and therefore the investment rate, assuming that the interest elasticity of savings is positive.

In April 1985 the government enacted a major banking reform as part of financial liberalization programme which aimed at changing the banks' structure. The reform carried provisions to change structural weaknesses in the banking system. A year earlier, in 1984, the Turkish government passed an act that allowed residents to open foreign currency accounts, which was an important step towards bringing Turkish banks closer to the EC standards. Furthermore, by a law passed on 29 June 1985, the banks were allowed to determine exchange rates for their commercial, noncommercial and interbank transactions. In addition, Decree 31(6 April 1985) replaced Decree 29 to establish a Fund to stabilize the cost of servicing the foreign loans received directly, by the banks or with the intermediation of the government for financing investments and foreign exchange earning activities. These provisions brought freedom and 
authority to the banks' operations as well as an institutional convergence for the EC and Turkish banking system.

The year 1986 marked the beginning of a transition period in the implementation of monetary policy which shifted the emphasis from direct interference in private and public sector portfolios to the determination of money and credit expansion through the control of total reserves of banking system. Also, in January, the Istanbul Stock Exchange started secondary market operations. On 2 April 1986 an inter-bank money market began operating where banks borrow and loan funds to each other anonymously with the intermediation of Central Bank, filling a structural gap in Turkish money market. The aim of the market was to bring banks with excess reserves and those in need of reserves into the marketplace.

The banking reform was strengthened by the 4 February 1987 decisions with which the Central Bank started open market operations with the purpose of implementing monetary policy. Also, banks were made more flexible in the management of their cash reserves and thereby the efficiency of open market operations was increased. Finally, in August 1988, structural changes took place in financial markets to create a system of market determined exchange rates. All in all, the banking reform and financial liberalization strategies were attempts to adjust the Turkish financial markets to those of the EC. The absence of financial freedom and the strict banking laws of the pre- 1980 period presented structural difficulties in the transactions between the European and the Turkish banks. For integration into the EC, those disparities had to be eliminated. Also, the rapidly changing European banking system and the financial integration in Europe necessitated a compatible monetary structure in Turkey.

There are several lines of argument linking the Turkish reforms to the Community. The EC, by its nature, is a highly protectionist body against non-member countries which pose a threat to the EC's common policies because many of their products are much cheaper due to lower labour costs. The Community, in response, increases its protective barriers further. Given this reaction, the non-member country views entry into the EC as an institutional adjustment necessary to avoid the negative repercussions of protectionism. 'Chez Jacques is the Brussels club that everyone in the neighborhood aspires to join', ${ }^{30}$ however, entry is not easy or always possible.

Since 1980 Turkey has been trying to adjust to the changes within the EC's internal structure and preparing for a customs union with the EC with an eye to full membership. Turkey is incorporated into the European 
economy via the 1963 Association Agreement-Ankara Treaty which ties Turkey and the EC firmly into trade and aid deals and which open up Turkey to the European standards. Two countries are said to be highly integrated when the shares of their total exports delivered to each other are higher in comparison to their deliveries to other countries. ${ }^{31}$ Thus, Turkey and the EC, taken as one trading bloc, are more-or-less integrated (see Tables 2 and 3). The situation being as it is, Turkey is vulnerable to any kind of change in the EC even when those changes do not immediately and directly concern Turkey such as the 1992 internal market.

In addition, with the 1970 Additional Protocol to the Association Treaty, Turkey has agreed to a customs union to be realized by the end of 1995. Turkey also applied to the EC for full membership in 1987, but joining the Community implies transforming the Turkish economy into a open market economy. ${ }^{32}$ The reforms after 1980 enabled the Turkish government to fulfil its obligations under the Protocol and to prepare its economy for the customs union and full membership. Those measures were as a whole an integral part of the government's major objective: integration with the European Economic Communities. ${ }^{33}$ All in all, economic developments since 1980 indicate that Turkey has gone through a major structural change in the direction of the free-market economy principle of the EC. Outward-looking economic policies pursued for the last ten years have increased the competitiveness of Turkish industry and facilitated integration with the European world. As an associate member preparing for full membership, Turkey is carefully following the developments aimed at the single market and is taking the necessary measures to orient its economy to the 1992 realities. $^{34}$

Since January 1994 the Turkish government has faced an acute balance of payments crisis which is reminiscent of the situation in 1980. On 5 April 1994 the Turkish government had announced a new Austerity and Stabilization Programme which covers three areas: (i) a tax reform; (ii) a privatization programme for the State Economic Enterprises; and (iii) depreciation of the Turkish lira. The reforms in these three areas aim at bringing the Turkish economic structure closer to the EU. Whether the Turkish economy will survive the 1994 economic and monetary crisis will be crucial in determining the realization of the customs union with the EU.

In short, the economic policies of the Turkish government have to be evaluated in the light of European integration because Turkey has to make certain readjustments in its economy in order first to survive in the post-1992 European economic order, and second to adjust gradually to the possibility of full membership in the EU and the 1995 customs union. 


\section{NOTES}

1. Ali Bozer, 'Major structural changes in Turkey', Export Magazine, Vol.6, No.16/17 (1989), p.5.

2. Turgut Özal's speech in the Turkish Parliament on 13 April 1987, Prime Ministerial Documents, 1987, p.256.

3. Mary Strang and Arlene Redmond (eds.), Turkey and the European Community (Brussels: A Forum Europe Conference, 1992), p.21.

4. For a more detailed analysis of the EC's response to the Turkish application, see the Commission's report titled 'The Turkish Economy: Structure and the Developments', $\operatorname{Sec}(89) 2290$, Final Annex, 18 Dec. 1989.

5. Loukas Tsoukalas, The European Community and the Mediterranean Enlargement (London: George Allen and Unwin, 1981), p.242.

6. Turkish State Planning Institute, European Communities Bulletin, Vol.1, No.3/4 (March 1990), pp.15-16.

7. The physical measures consist of abolishing frontier controls on goods and persons, and eliminating non-tariff barriers to trade. The fiscal measures aim at eliminating all obstacles and significant distortions among the members that derive from differences in the product and in the rates of both value added and excise tax. Finally, the technical barriers, presented by lack of technical harmonization, public procedures, institutional obstacles to the free movement of labour, lack of European patent and trademark issues of corporate taxation are to be removed.

8. The financial integration can be traced back to 1979, the establishment of the European Monetary System (EMS) and the 1989 Delors package furthered the EMS and proposed a three stage plan for European Monetary Union.

9. The Economist, 22 April 1989, Vol.311, No.7599, p.18.

10. Asim Erdilek, 'The Financial Integration of the European Community in Project 1992', Case Western Law Review, Vol.21, No.2 (March 1991), p. 249.

11. Michael Plummer, 'Efficiency effects of the accession of Spain and Portugal to the EC', Journal of Common Market Studies, Vol.29, No.3 (March 1991), p.322.

12. Dudley Seers and Constantine Vaitsos, The second enlargement of the EEC (New York: St. Martin's Press, 1982), pp.9-13.

13. Finn Laursen, 'The EC and its European neighbors: special partnership or widened membership?', International Journal, Vol.47, No.1 (Winter 1991-92), p.32.

14. Christopher Bliss and Jorge Braca de Macedo (eds.), Unity within Diversity in the European Economy; The Community's Southern Frontier (Cambridge: Cambridge University Press, 1990), p.7.

15. Demir Demirgil, 'From the economic point of view, do you think Turkey should join the EC?', Export Turkey Magazine, Vol.6, No.16(Winter 1989), p.7.

16. Tosun Aricanli and Dani Rodrik, The Political Economy of Turkey (New York: St. Martin's Press, 1990), p.10.

17. Tevfik Nas and Mehmet Odekon, Liberalization and the Turkish Economy (London: Greenwood Press, 1988), p.2.

18. George Kopits, Structural Reform, Stabilization and Growth in Turkey (Washington, DC: International Monetary Fund Paper No.52, 1987), p.1.

19. Anne Krueger, Foreign Trade Regimes and Economic Development: Liberalization Attempts and Consequences (Cambridge: Ballinger Press, 1978), p. 37.

20. Nas and Odekon, Liberalization and the Turkish Economy, p.2.

21. The Economist, 'Turkey: half inside, half outside', 18 June 1988, Vol.307, No.7555, p.23.

22. In a report prepared by the State Planning Institute it was indicated that the reform program was adopted in order to facilitate Turkish integration into the EC, with the aim of eliminating the gap that existed between the product, factor, financial and foreign trade markets of EC and Turkey. Presidency for the Relations with the EC, The European Communities Bulletin, Turkish Prime Ministry Documents, Vol.1, No.2 (Feb. 1990), p.5. 
23. Interview with Turgut Özal, Economic Dialogue, No.30(May 1989), p.7.

24. Presidency for the Relations with the EC, European Communities Bulletin, State Planning Institute of Turkish Prime Ministry, Vol.1, No.3 (March 1990), p.16.

25. In Table 5 one can observe the tariff reductions implemented by the government on imports, realized through government trade tax revenues divided by the value of imports.

26. Presidency for the Relation with the EC, 'EC Bulletin', Turkish Prime Ministry Documents, Vol.1, No.2(Feb. 1990), p.6.

27. Tercan Baysan and Charles Blitzer, 'Turkey's Trade Liberalization in the 1980s', in Dani Rodrik and Tosun Aricanli (eds.), The Political Economy of Turkey (New York: St. Martin's Press, 1990), p.25.

28. Kopits, Structural Reform, p.19.

29. An interview with Rusdu Saracoglu-Governor of the Turkish Central Bank, 'Over the hump, but not yet home: survey of Turkey', Euromoney, March 1989, p.181.

30. 'European Community; a power in its own right', The Economist, 7-13 July 1990, Vol.316, No.7662, p.12.

31. A. Shachar and S.Oberg, The world Economy and Spatial Organization of Power (Avebury: Gower press, 1990), p.84.

32. Commission of the European Communities, Report on Turkish application for accession, 'Turkish Economy: Its Structure and the Developments', 18 Dec. 1989, Final Annex, Brussels, $\sec (89) 2290$, p.49.

33. Bozer, 'Major Structural Changes', p.5.

34. Ali Bozer's speech for ECACC's-European Council of American Chambers of Commerce - silver anniversary meeting held in Istanbul in 1989.

35. State Statistics Institute-Devlet Istatistik Enstitusu, Ankara, various reports on foreign trade.

36. State Statistics Institute, Foreign Trade Statistics, 1992, p.7.

37. State Statistics Institute, p.24.

38. OECD Statistics of Foreign Trade, Series C, Trade by Commodities, Market Summaries; Imports Jan.-Feb. 1977.

39. State Planning Institute, Foreign Trade Statistics (Ankara, 1986), p.156.

40. Baysan and Blitzer, 'Turkey's Trade Liberalization', p.12. 